\title{
Penelitian Pendahuluan Bioekologi Ikan Terubuk di Perairan Bengkalis, Riau
}

\author{
Thamrin \\ Dosen Pascasarjana Ilmu Lingkungan Program Pascasarjana Universitas Riau, Pekanbaru \\ e-mail: daffa_sidqi@yahoo.com
}

\begin{abstract}
Terubuk (Tenualosa macrura)is an endangered and under protected species in Riau Province. A series survey activity was conducted at least one time in a week (in May to November 2016) at Bengkalis regency waters for knowing the development of gametes and fish oocytes. However, the survey activities were not carried out in June to August. The result shows that the T. macrura was not spawning simultaneously among individuals; however when removing eggs and sperm were carried out simultaneously or totally released between oocytes and sperm, with the most spawning occurs in September each year.
\end{abstract}

\section{Key words: Gametogenesis, oosit, sperms, spawning, Tenualosa macrura}

Penelitian tentang reproduksi pada ikan telah banyak dilakukan, baik pada ikan sungai maupun ikan laut, baik penelitian dalam bentuk sederhana yang masih memakai peralatan sangat terbatas maupun yang telah menggunakan teknologi terkini sampai meninjau dari sudut rekayasa genetik. Penelitian tentang bioekologi dan siklus reproduksi pada ikan juga telah dilakukan secara luas terhadap beragam jenis dan beragam ukuran jenis ikan, dari jenis ikan yang berada di daerah tropis sampai pada jenis ikan yang ditemukan di daerah kedua kutub utara dan selatan di bumi.

Indonesia memiliki sumberdaya alam yang berlimpah, dengan berbagai sumberdaya air tawar dan sumber daya air laut beragam. Sehingga Indonesia terkenal dengan mega biodiversity dunia, yang hanya bisa disaingi oleh hutan Amazon yang ada di Amerika Latin. Namun hasil penelitian secara umum tetang bioekologi dan reproduksi tentang ikan air tawar baik yang hidup di air tawar maupun di air laut masih sangat terbatas. Begitupun berhubungan dengan penelitian bioekologi dan siklus reproduksi ikan di Indonesia masih jauh lebih sedikit bila dibandingkan dengan penelitian topik yang sama di negera lain. Apalagi dibandingkan dengan luas perairan laut dan jumlah penduduk yang dimiliki Indonesia seolah-olah tidak sebanding dengan hasil penelitian berhubungan dengan penelitian bioekologi dan siklus reproduksi ikan. Penelitian reproduksi pada ikan sendiri secara umum belum banyak yang dilakukan di Indonesia, dan lebih banyak dilakukan pada kelompok ikan yang hidup di perairan darat (ikan air tawar) dibandingkan dengan ikan laut walaupun sekitar $70 \%$ luas Indonesia.

Penelitian siklus reproduksi pada ikan juga telah banyak dilakukan, terutama terhadap jenis-jenis ikan yang hidup di daerah terumbu karang (Fahy et al. 2007; Medeiros et al., 2009), akan tetapi yang dilakukan di Indonesia masih sangat terbatas. Penelitian siklus reproduksi ikan sebagai sumberdaya perairan pada dasarnya diantaranya bermanfaat dalam mempermudah usaha budidaya perikan khususnya dalam bidang pembenihan. Kondisi ini sangat dibutuhkan terutama berhubungan dengan kelompok ikan yang hidup di alam dimana pada umumnya setiap oragnisme memiliki siklus gametogenesis yang jelas dan tetap. Akan tetapi pada ikan yang dipelihara di dalam kurungan, baik di dalam kurungan maupun di dalam kolam, proses pematangan gamet bisa dikondisikan sesuai dengan waktu yang tersedia, dengan pemacu pematangan gamet menggunakan pemberian makanan berkualitas yang dibutuhkan untuk meransang gametogenesis.

Meski penelitian reproduksi pada ikan secara umum telah banyak dilakukan di Indonesia sebagai mana disebutkan di atas, namun masih terfokus pada topik pematangan gonad dan hubungannya dengan pembenihan. Kemudian pengamatan yang dilakukan juga 
lebih banyak diarahkan pada jenis-jenis ikan perairan tawar, dan sebaliknya masih terbatas dilakukan pada jenis-jenis ikan yang terdapat di perairan laut. Disamping itu penelitian yang dilakukan dalam rentang waktu yang relatif lama seperti siklus reproduksi masih relatif dalam jumlah terbatas dan jarang dilakukan di Indonesia. Penelitian yang berhubungan dengan siklus reproduksi sebenarnya mengarah pada penelitian dasar, akan tetapi sangat diperlukan karena akan berhubungan dengan waktu pemijahan pada ikan dan juga dengan manajemen sumberdaya perairan.

Ikan Terubuk (Tenualosa macrura) adalah salah satu ikan ekonomis penting dengan nilai jualnya sangat mahal, terutama harga telurnya. Ikan terubuk menjadi buruan termasuk nelayan yang beroperasi di Perairan Bengkalis Riau. Keadaan ini tidak saja berujung pada penurunan sumberdaya perairan (eksistensi ikan terubuk), bahkan perburuan terhadap jenis ikan ini telah menyebabkan ikan terubuk menjadi jenis ikan langkah. Penelitian tentang ikan terubuk telah dilakukan Efizon et al. (2012), akan tetapi masih terfokus pada kondisi populasi ikan tersebut, namun berhubungan dengan bioekologi dan siklus reproduksi Ikan terubuk di Perairan Bengkalis (Selat Malaka) belum pernah dilakukan. Untuk menjaga keberlanjutan ikan terubuk maka dirasa perlu untuk melihat makanan siklus reproduksi pada ikan tersebut sebagai awal penelitian. masih sangat terbatas dilakukan di Riau khususnya dan di Indonesia umumnya.

\section{BAHAN DAN METODE}

\section{Tempat dan Waktu}

Penelitian ini dilakukan di Perairan Bangkalis dan sekitarnya, dan sampel diperoleh dari nelayan baik yang berada di Bangkalis. Sampel diambil dari hasil tangkapan Nelayan minimal sekali dalam sebulan yang ditangkap menggunakan alat tangkapan gilnet. Waktu pengambilan sampel berlansung direncanakan 12 bulan, tetapi hanya 7 kali pengambilan sampel yang terlaksana. Penelitian dimulai Bulan Mei, kemudian terhenti dan dimulai lagi bulan September 2017. Dari September baru diambil minimal sekali dalam satu bulan menjelang Septembr 2017.
Sampel yang menjadi ukuran dalam penelitian ini tergantung pada hasil tangkapan ikan yang diperoleh oleh nelayan. Berhubung jenis ikan tergolong ikan yang dilindungi, maka agak sulit untuk mendapatkannya. Nelayan yang menjadi penangkap ikan terubuk ini berasal orang yang berbeda, yang mencari ikan disebelah selatan Pulau Bengkalis. Ikan terubuk didapat dari perairan Bengkalis, dimana daerah tersebut menjadi daerah penangkapan ikan biasanya.

Berhubung ikan ini tergolong kelompok yang langkah (yang dilindungi), sehingga total sampel setiap kali pengambilan terbatas. Ratarata sampel berkisar antara 10 ekor sampai 12 ekor. Ukuran sampel lebih banyak yang berukuran besar, sehingga sampel condong berkelamin betina. Kondisi ini disebabkan ikan terubuk bersifat hermaprodit singroni, yang menyebabkan sampel pada saat kecil berukuran jantan dan kemudian dalam ukuran tertentu berubah menjadi betina.

Data yang diambil dalam penelitian ini terdiri dari Ukuran Panjang Total (SL), Panjang Standar (TL) dan berat ikan sendiri. Data yang diambil/diukur dari sampel yang diperoleh meliputi data panjang ikan, data berat ikan, data berat gamet, fekunditas telur dan diameter telur. Ikan sampel yang telah dikumpulkan terlebih dahulu diawetkan menggunakan es kristal untuk menjaga sampel tetap segar, serta data ukuran panjang dan berat ikan, berat gamet (telur) akan diukur lansung di laboratorium Bioper Fakultas Perikanan Universitas Riau. Begitupun untuk diameter telur dan fekunditas telur diamati di labotorium Fakultas Perikanan dan Ilmu Kelautan Universitas Riau.

Untuk pengawetan sampel ikan dan gamet ikan terubuk akan digunakan es kristal. Disamping sampel ikan terubuk yang akan disampel setiap bulan yang diperkirakan akan memakan waktu sampai beberapa bulan nantinya. Beberapa peralatan yang digunakan diantaranya: plastik tempat sampel gamet, timbangan untuk mengkur berat ikan sampel dan timbangan untuk mengukur berat gamet, satu set mikroskop untuk mengamati gamet di laboratorium, luv untuk pengamatan gamet di lapangan, termometer untuk mengukur temperatur air, refraktometer untuk mengukur salinitas air, sechi disk untuk mengukur 
kecerahan perairan, pinset dan gunting bedah untuk membedah ikan.

Sampel ikan Terubuk (T. Macrura) diambil pada bulan Mei dan sampai Bulan September 2017 baru terjadi pengambilan sampel kembali. Kondisi ini berhubungan dengan kondisi kesehatan yang tidak memungkinkan untuk mengambil sampel. Dari bulan September 2017 kembali mengambil sampel minimal sekali dalam sebulan. Sampel yang digunakan berasal dari hasil tangkapan nelayan di Pulau Bengkalis, dengan penangkapan ikan dilakukan di daerah bagian Utara Pulau Bengkalis, dan nelayan Sungai Pakning tersebut menggunakan gilnet dalam penangkapannya.

\section{Analisis Data}

Untuk melihat hubungan panjang dan berat ikan dilakukan regresi linier. Ukuran ikan yang dipakai berasal dari semuah ikan yang diambil selama penelitian, dari bulan Mei, September dan oktober. Berhubung jumlah ikan dari kelompok jantan hanya 3 ekor maka dalam analisis ini dikeluarkan dalam dari perhidtungan. Namun data ini hanya dimasukan untuk analisis deskriptif.

Hubungan bobot tubuh dengan panjang standar dan panjang total ikan kurau yang berasal dari perairan Bengkalis, Riau digabungkan antara jantan dan betina dengan menggunakan rumus Ricker (1975) sebagai berikut:

$$
\begin{aligned}
& \mathrm{W}=\mathrm{aLb} \\
& \text { Dimana: } \\
& \mathrm{W}=\text { Bobot ikan (gram) }
\end{aligned}
$$

$$
\mathrm{L}=\text { Panjang Total ikan }(\mathrm{cm})
$$

A dan $\mathrm{b}=$ Konstanta regresi eksponensial Kematangan ikan terubuk akan ditentukan berdasarkan tingkat kematangan gonad (TKG), yaitu dengan melihat tanda-tanda umum dan ukuran gonad (modifikasi metoda Cassie dalam Effendie, 1979). Data yang didapatkan diolah dalam bentuk hubungan panjang berat, Tabel dan Gambar, kemudian data yang diperoleh akan dianalisis secara deskriftif

\section{HASIL}

Penangkapan ikan terubuk dilakukan pada malam dan siang hari dan pada dasarnya tergantung pada kondisi angin saat tersebut. Berhubungan dengan waktu tersebut diperoleh suhu air rata-rata hampir sama, yaitu $30^{\circ} \mathrm{C}$. Sementara untuk salinitas juga diperoleh demikian, yaitu $28-30 \%$ o.

Hubungan panjang dan berat ikan terumbuk (T. Macrura) diperoleh bahwa ikan ini dengan nilai hubungan sangat erat. Dengan nilai yang dutunjukan termasuk berhubungan sangat kuat, dimana panjang ikan memiliki hubungan erat dengan beratnya.

Hubungan antara panjang ikan terubuk dan berat terubuk diperoleh bahwa pertumhan panjang ikan sejalan dengan pertambahan berat ikan. Atau dengan terjadi pertambahan panjang ikan terubuk maka ikan mengalami pertambahan berat ikan terubuk. Hubungan ini menunjukkan ikatan sangat erat, kondisi ini ditandai oleh nilai $\mathrm{R}^{2}=0,87$.

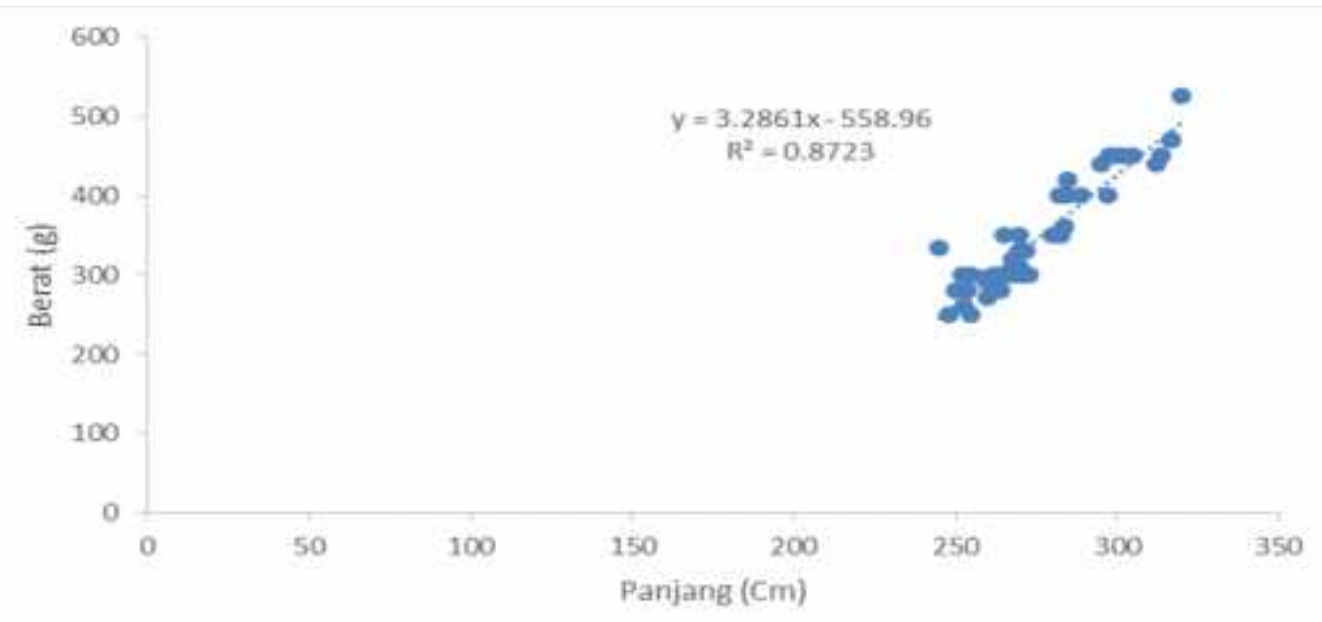

Gambar 1. Hubungan Panjang Berat Ikan Terubuk. Data Diakumulasikan Dari Hasil Tangkapan selama Penelitian. 
Pengamatan gametogenesis atau tingkat kematangan gonad ikan jantan dan betina dilakukan selama 7 bulan. Pengamatan lebih difokuskan pada telur terubuk digolongkan dalam lima tahap, yaitu TKG I (belum berkembang), II (perkembangan awal), III (sedang berkembang), IV (matang) dan V (pasca pemijahan) baik pada ikan betina maupun jantan yang mengacu pada modifikasi Cassie (Effendi, 1992) dan Chinabut et al. (1991). Tingkat perkembangan gonad ikan Terubuk betina seperti berikut.

Tabel 1. Kriteria penilaian tingkat kematangan oosit ikan terubuk.

\begin{tabular}{|c|l|}
\hline TKG & \multicolumn{1}{|c|}{ Morfologi } \\
\hline $\begin{array}{c}\text { I } \\
\text { (belum berkembang) }\end{array}$ & $\begin{array}{l}\text { Ovarium berbentuk dua kantong kecil, mengisi sekitar 1/8 rongga perut. } \\
\text { Permukaan ovarium licin dan berwarna merah muda. }\end{array}$ \\
\hline $\begin{array}{c}\text { II } \\
\text { Perkembangan awal) }\end{array}$ & $\begin{array}{l}\text { Ukuran ovarium lebih besar dari TKG I dan mengisi sekitar 1/6 rongga } \\
\text { perut. } \\
\text { Ovarium berwarna merah gelap, dan telur belum terlihat jelas dengan } \\
\text { mata. }\end{array}$ \\
\hline $\begin{array}{c}\text { III } \\
\text { (sedang berkembang) }\end{array}$ & $\begin{array}{l}\text { Ovarium berwarna merah condong hitam, mengisi 1/3-1/2 rongga } \\
\text { perut. Butir telur terlihat dengan mata, tersusun berangkai dan tidak } \\
\text { dapat dipisahkan. }\end{array}$ \\
\hline $\begin{array}{c}\text { IV } \\
\text { (matang) }\end{array}$ & $\begin{array}{l}\text { Ovarium memiliki warna kuning, mengisi sekitar 2/3 rongga perut. } \\
\text { Telur berwarna kuning tersusu rapat, dan butiran telur mudah } \\
\text { dipisahkan. }\end{array}$ \\
\hline $\begin{array}{c}\text { V } \\
\text { (pasca pemijahan) }\end{array}$ & $\begin{array}{l}\text { Ovarium mengisi sekitar 1/4 rongga perut dan agak berkerut. Ovarium } \\
\text { berwarna pucat, dan butir sisah tersusun jarang. }\end{array}$ \\
\hline
\end{tabular}

Ikan terubuk pada dasarnya hermaprodit Singkroni, dimana pada ukuran kecil bersifat jantan, sementara yang berukuran besar berubah menjadi betina. Ikan terubuk jantan untuk sementara waktu ditemukan dengan kisaran berat $200-250 \mathrm{~g}$, panjang total dengan kisaran 218-228 Cm, dan panjang standar dengan kisaran 223-235 Cm. Sementara ukuran yang betina memiliki kisaran antara 230 - $525 \mathrm{~g}$ dengan kisaran ukuran total 341 - 403 g, dengan panjang total dengan kisaran $230-320 \mathrm{Cm}$. Sementara ukuran paling kecil ikan terubuk yang disebut piyai oleh masyarakat hanya dijumpai dalam jumlah kecil. Sehingga belum bisa ditentukan ikan terubuk mulai matang secara reproduksi.

Pengambilan sampel ikan Terubuk dimulai dari tanggal 11 Mei sampai bulan November 2017. Kemudian tiga bulan berikutnya terhenti, dan baru bulan September dilakukan kembali pengambilan sampel. Pada setiap kali pengambilan sampel tidak seluruh besar ikan Terubuk yang didapat, dan lebih banyak ikan berukuran besar yang yang diperoleh. Berhubung ikan ini bersifat hermaprodit singkroni, makanya yang selalu didapat jenis ikan yang betina, yaitu yangberukuran besar. Sementara yang berjenis ikan jantan (berukuran kecil) hanya diperoleh pada bulan September dua kali sampling dan pada bulan Novermber 2017. Sementara empat bulan lain tidak diperoleh ikan yang berukuran kecil atau yang jantan.

Untuk pengambilan sampel bulan Mei tidak ditemukan kelompok ikan terubuk yang jantan. Kelompok jantan memiliki ukuran lebih kecil karena ikan ini bersifat hermaprodit singkroni, yaitu yang berukuran kecil jantan dan yang berukuran betina lebih besar. Keadaan ini disebabkan ikan yang diperoleh hanya yang berukuran tubuh besar, yang pada dasarnya sudah berubah menjadi kelompok betina semuanya. 


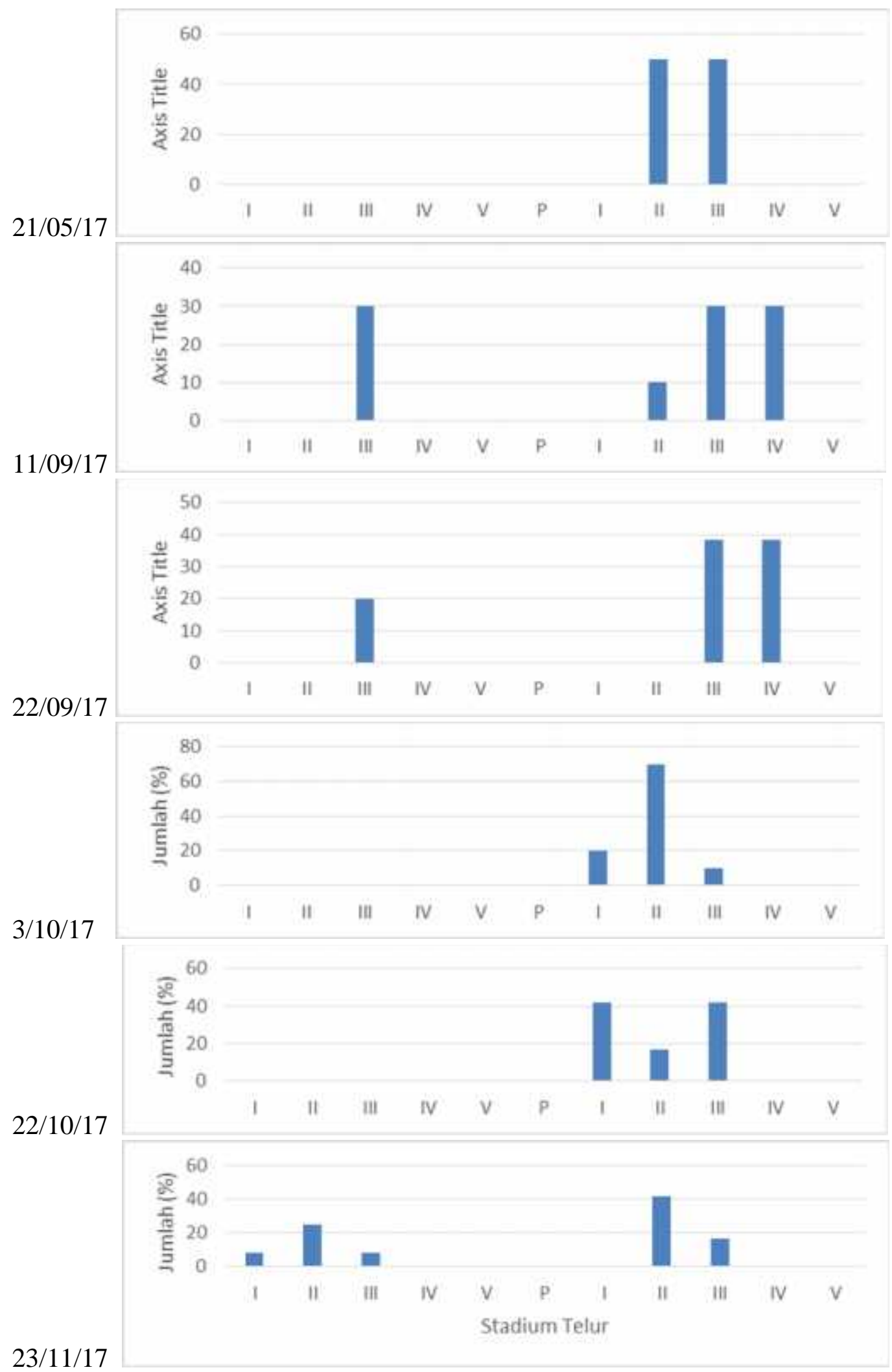

Gambar 2. Perkembangan gamet ikan Terubuk jantan dan betina dari sampel yang diambil 21 Mei-11 November 2017. Kiri Stadium Testis dan di kanan telur. $\mathrm{P}=$ perubahan dari testis ke telur

Melihat perkembangan gamet ikan Mengingat perkembangan gametnya terutamah terubuk secara keseluruhan, mulai dari bulan oosit yang terdeteksi pada bulan lima masih Mei sampai bulan November untuk sementara Stadium III. Sementara perkembbangan oosit terlihat spawning terjadi pada bulan September. dua bulan terakhir juga ukuran terbesar oositnya 
masih tergolong stadium III. Spawning pada ikan Terubuk ditemukan baik pada waktu terang bulan maupun pada saat bulan mati.

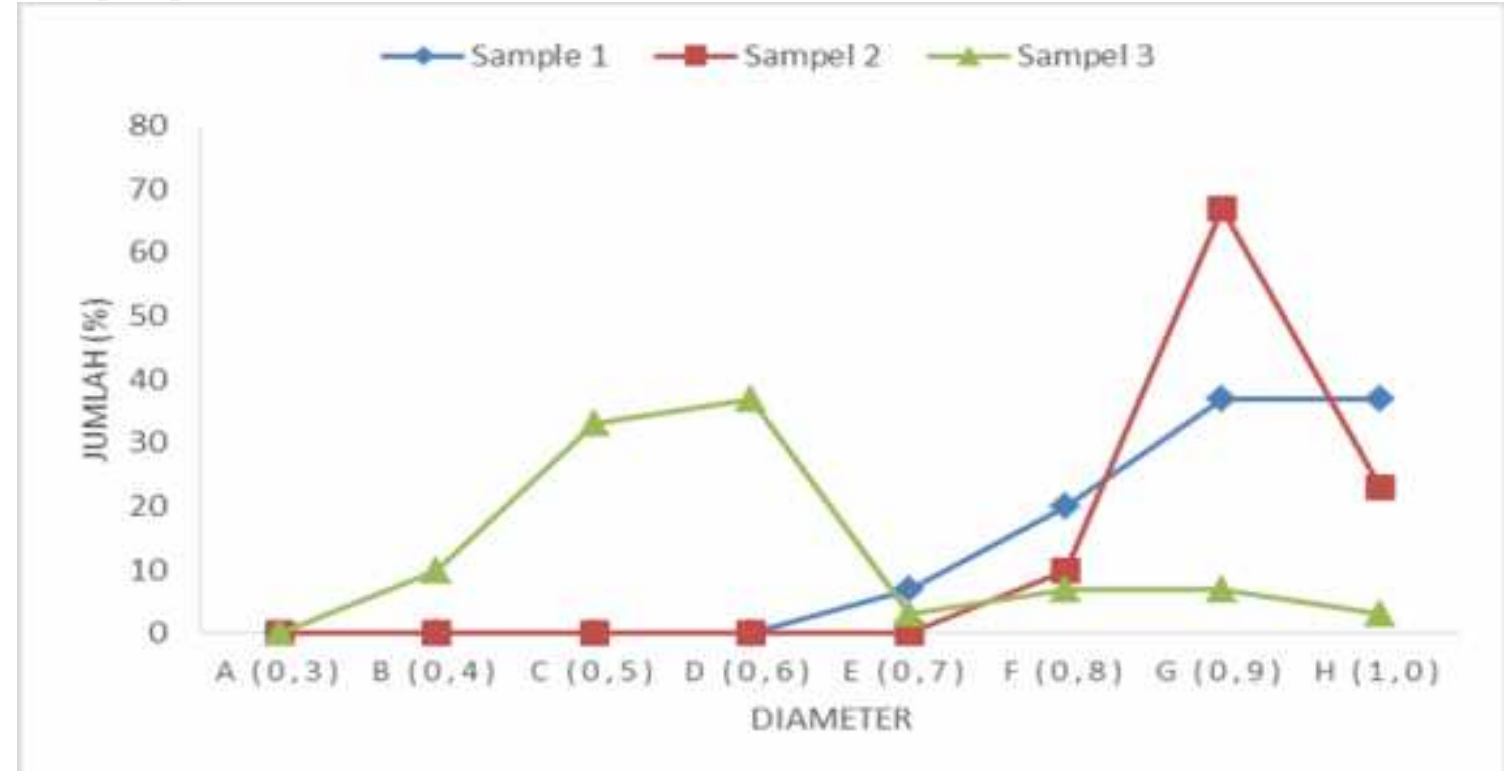

Gambar 3. Sebaran diameter Telur pada TKG III dan IV pada oosit yang diambil selama penelitian.

Dari tiga ikan sampel Gambar 3 memperlihatkan ada perbedaan ukuran diameter oosit yang beragam pada setiap sampel (tanggal 27 Mei 2017 atau pada tanggal 27 bulan Arab). Ukuran telur (segi tiga kuning) memiliki ukuran terkecil 0,4 memiliki jumlah 10 persen, dan ukuran terbesar berada pada diameter 0,6 dengan kisaran sekitar $37 \%$, serta sebagian kecil telah mencapai 1,0 mm. Sementara yang petak biru memiliki distribusi telur dari yang berdiameter $0,7 \mathrm{~mm}$ berjumlah sekitar $5 \%$, berdiameter 0,8 memiliki jumlah sekitar $20 \%$, dan yang berdiameter $0,9 \mathrm{~mm}$ dan $1,0 \mathrm{~mm}$ memiliki jumlah sekitar $30 \%$. Sehingga terlihat bahwa tingkat kematangan gonat ikan terubuk tidak sama diantara satu individu dengan individu lainnya.

\section{PEMBAHASAN}

Hubungan antara temperatur dan salinitas tidak begitu terjadi perubahan dalam penelitian ini. Temperatur pada siang hari berkisar $30^{\circ} \mathrm{C}$ sampai $31^{\circ} \mathrm{C}$, sementara salinitas sekitar $28 \%$ sampai $30 \%$. Perbedaan kualitas air ini tidak mungkin menjadi faktor yang menyebabkan perubahan kelamin dari jantan ke betina pada ikan terubuk. Pola ini bukan berhubungan dengan temperature, kecerahan perairan atau salinitas (Alexandre et al. 2004). Berbeda
Kondisi ini terlihat lagi pada petak merah (Gambar 3), dimana telur berdiameter 0,8 mm memiliki jumlah sekitar $10 \%$, dan telur berdiameter $0,9 \mathrm{~mm}$ memiliki jumlah $70 \%$, sedangkan yang berdiameter $1,0 \mathrm{~mm}$ memiliki jumlah $20 \%$. Maka dari gambar ini dapat diambil kesimpulan bahwa ikan terubuk pada dasarnya mengeluarkan telur secara serentak.

Setelah melakukan spawning maka seluruh ikan betina mengeluarkan seluruhnya oosit dan ikan jantan juga mengeluarkan sperma seluruhnya atau secara total. Bagi ikan terubuk yang telah mengeluarkan telurnya maka ikan tersebut akan kembali kehabitat awalnya. Hal dibenarkan oleh nelayan-nelayan terubuk bahwa setelah ikan melakukan peminjahan, akan keluar pada anusnya dalam bentuk lendir baik yang jantan maupun yang betina.

dengan Cichlasoma dimersu yang diatur oleh kedua temperatur dan cahaya matahari (Fizbein et al., 2010), sebagai mana terjadi di teleotei yang lain (Batlaoni et al. 2006 dan Sing et al. 2010) yang meterangkan tentang GSI yang terjadi frekwensi.

Hubungan panjang dan berat ikan akan diketahui apakah berat dipengaruhi oleh panjang ataupun tidak. Pada ikan yang dipengaruhi oleh ukuran panjang terhadap berat maka jenis ikan 
ini tidak tergantung pada ukuran panjang, maka ikan akan tetap berkembang sepanjang tahun. Ikan terubuk ini tidak tergantung pada panjang ikan, dan panjang ikan memiliki hubungan yang erat dengan ukuran berat. Pertumbuhan pajang ikan bertambah dengan pertamban panjang ikan.

Ikan Terumbuk (T. Macrura) adalah ikan yang bersifat hermaprodit. Ikan ini pada waktu kecil bersifat jantan dan setelah dewasa berubah kelamin ke betina. Jenis hermaprodit ini tersebar diantara ikan, dengan estimasi rentang from jumlah ondo sekitar 7 sampai 9 (Kiu et al. 2016). Jumlah ini diperkirakan sekitar $2 \%$ spesies ikan diperkirakan bersifat hermaprodit (Sadovy de Mitcheson dan Liu, 2008; Avise and Mark, 2009).

Siklus reproduksi pada ikan mungkin berupa tahunan atau berupa dalam ukuran bulan tertentu. Siklus reproduksi seperti ini biasanya ditemukan pada ikan yang ada di daerah tropis. Sementara ikan berada di daerah beriklim subtropis biasanya mengalami siklus yang jelas, dan ikan melakukan gametogenesis pada periode pendek atau yang panjang sesuai dengan tempatnya menetap. Pada jenis ikan yang melakukan siklus tahunan pada umumnya yang hidup di daerah yang memiliki 4 musim atau di daerah sub-tropis.

Sementara sebagai ikan dari kelompok hermaprodit singroni, menyebabkan terjadi perubahan kategori TKG yang beragam. TKG ikan yang telah berubah menjadi kelamin betina terjadi dengan ukuran berat tubuh 250 g sampai $535 \mathrm{~g}$, sedangkan total panjang lebih pendek yakni 320 sampai $403 \mathrm{Cm}$. Sementara ikan tersebut memiliki panjang total (SL) $230 \mathrm{Cm}$ sampai $320 \mathrm{Cm}$. Sementara untuk ukuran jantan dijumpai $200 \mathrm{~g}$ sampai $250 \mathrm{~g}$, ukuran panjang total $310 \mathrm{Cm}$ sampai $328 \mathrm{Cm}$, dan panjang standar antara $225 \mathrm{Cm}$ sampai $235 \mathrm{Cm}$ (Lampiran 2 - 11). Jadi untuk melihat apakah ikan tersebut jantan atau betina kemungkinan pada ikan terubuk di perairan Bengkalis lebih condong berdoman pada berat ikan.

Ikan terubuk adakalanya memiliki tubuh yang bongsor, sehingga tidak bisa berpedoman pada berat, akan tetapi menentukan jantan atau betina tetap melalui perbedaan berat tubuhnya. Pada berat $250 \mathrm{~g}$ ditemukan kedua jenis ikan jantan dan betina. Pada ukuran ini diperkirakan terjadi peralian antara jantan dan betina, sehingga bila dalam keadaan jantan adalah merupakan terakhir kalinya ikan tersebut dalam kondisi jantan. Tetapi bila dalam kondisi betina adalah yang pertama kali pula dalam keadaan betina, dan seterusnya akan betina selamanya. Tetapi kalau melihat pada panjang total, seperti terdapat pada ikan jantan sudah berukuran 328 $\mathrm{Cm}$, sementara pada ukuran betina jantan adakalanya $320 \mathrm{Cm}$. Terdapat $8 \mathrm{Cm}$ tidak sesuai dengan hipotesa yang dalam membedakan betina dan jantan.

Bila dilihat dari ukuran panjang standar lebih jauh lagi perbedaan atau peralihan penggantian oosit dan sperma tersebut. Kalau dari perbedaan berat, peralihan antara jantan ke betina hanya pada berat $250 \mathrm{~g}$. Ikan yang berat tersebut munkin jantan, dan disisi lain mungkin betina. Dilihat dari panjang standar ini ditemukan ikan betina dimulai dari panjang 320 $\mathrm{Cm}$, sementara ukuran standar ikan jantan masih ditemukan pada ukuran $235 \mathrm{Cm}$. Perbedaan ukuran peralihan antara jantan dan betina memiliki selisih $5 \mathrm{Cm}$. Maka disimpulkan bahwa untuk melihat peralihan ikan terubuk ikan jantan atau betina lebih condong ke berat ikan, karena ikan ini memiliki berat yang sama antara ikan jantan maupun ikan betina ( $250 \mathrm{~g})$.

Pada ikan terubuk diperkirakan memiliki satu kali spawning dalam setahun untuk individu yang sama, akan tetapi diantara individu dengan yang lainnya mengalami waktu berbeda-beda. Keadaan ini merujuk pada pengambilan sampel pada bulan Awal September sudah memiliki TKG II, III dan IV. Sementara oosit dan sperma melakukan spawning secara sekaligus semuanya, dan hal ini diperkuat oleh nelayan setelah memijah akan ditemukan ikan terubuk masih mengeluarkan sisah-sisah sperma atau telur di anusnya.

Dari data yang diperoleh selama penelitian bahwa selama ikan terubuk memijah diperkirakan sekitar bulan September 2017. Tetapi tidak tertutup kemungkinan lebih lama dari perkiraan tersebut, disebabkan waktu dan jumlah sampel yang diperoleh dalam jumlah terbatas. Begitupun hasil sampel pada bulan Mei, dimana jumlah sampelmya sedikit. Kemudian dua bulan kemudian, Juni dan Agustus juga tidak dilakukan pengambilan sampel disebabkan faktor kesehatan.

Mengacu pada penelitian ini waktu memijah ikan terubuk terjadi selama satu bulan, karena TKG IV ditemukan selama bulan 
September tersebut. Kemudian pada bulan berikutnya ditemukan hanya TKG I, TKG II dan TKG III. Sementara di Perairan Karachi-Sind Pakistan, Hoda dan Qureshi (1989) menemukan bahwa ikan dengan postur hampir sama ditemukan lebih lama melakukan spawning, yaitu antara bulan Oktober sampai bulan Maret. Sementara sistem reproduksi pada $C$. dimerus diatur oleh kedua kondisi temperature dan kondisi photoperiod (Fiszbein et al. 2010), sebagaimana terjadi pada ikan lain (Bromage et al. 2001; Cinquetti and Dramis 2003; Alvarenga et al. 2006; Batlouni et al. 2006; Singh et al. 2010), yang menunjukan perkembangan frekwensi oosit spawning terdeteksi selama penelitian.

Dalam penelitian ini diperkirakan waktu spawning lebih lama, akan tetapi setiap individu ikannya melakukan spawning secara total (Gambar 3). Karena dari hasil perkembangan gamet menunjukan tingkat kematangan TKGnya berbeda-beda. Namun pada saat spawning, baik jantan maupun yang betina akan mengeluarkan sperma dan oosit sekali gus. Akan tetapi jumlah musim mass-spawning terjadi di bulan September 2017. Sementara di alam, yang terjadi pada $C$. dimerus barangkali musim pemijahan, dan tidak terjadi reproduksi selama outum sampai winter. Beberapa penelitian sebelumnya yang terjadi pada ikan yellow stingray Urobatis jamaicencis betina memiliki dua siklus reproduksi dimana yang betina mampu melakukan reproduksi dua periode setiap tahun, kelahiran pertama terjadi antara bulan June - April dan yang kedua terjadi antara bulan November - Januari setiap tahun di Tenggara di perairan terumbu karang USA (Fahy et al., 2007). Sementara pada ikan Sleeper, Eleotris acanthopoma ditemukan bahwa periode spawning E. acanthopoma dimulai oleh perpanjangan hari dan peningkatan temperatur air pada awal musim panas, dan ditentukan dengan memperpendek periode hari pada akhir periode reproduksi di Muara Sungai Kaoping Cina (Wang et al., 2003).

Sementara pada ikan Sleeper, Eleotris acanthopoma ditemukan bahwa periode spawning E. acanthopoma dimulai oleh perpanjangan hari dan peningkatan temperatur air pada awal musim panas, dan ditentukan dengan memperpendek periode hari pada akhir periode reproduksi di Muara Sungai Kaoping
Cina (Wang et al., 2003). Sementara pada penelitian ini tidak berhubungan dengan temperatur maupun salinitas, karena perubahan kedua faktor lingkungan tersebut tidak kentara.

\section{SIMPULAN}

Dari enam kali pengambilan sampel terhadap ikan terubuk dapat disimpulkan sebagai berikut:

1. Ikan terubuk termasuk jenis ikan hermaprodit singkroni, dimana waktu kecil sampai ukuran tertentu bersifat jantan dan setelah besar berubah menjadi betina. Dan dari penelitian ini tidak ada pengaruh parameter lingkungan yang diukur yang berpengaruh pada ikan terubuk.

2. Ikan terubuk memiliki gametogenesis atau perkembangan gonat oosit dan sperma sepanjang tahun. Setelah ikan terubuk memijah atau spawning kembali muncul terutama oosit yang lebih kecil.

3. Ikan terubuk mengalami mass spawning pada bulan September setiap tahunnya, namun disangsikan mengalami lebih dari sekali melakukan spawning dalam setahun, tetapi disebabkan beberapa kali pengambilan sampel tidak tergambar secara utuh.

\section{UCAPAN TERIMA KASIH}

Terimakasih saya ucapkan kepada Tuhan Yang Maha Esa atas berkat yang diberikan kepada saya. Terimakasih kepada semua pihak yang telah membantu baik material maupun non material demi mendukung saya dalam penelitian ini

\section{DAFTAR PUSTAKA}

Alexandre M. Garcia, João P. Vieira, Kirk O. Winemiller and Marcelo B. Raseira. 2004. Reproductive cycle and spatiotemporal variation in abundance of the one-sided livebearer Jenynsia multidentata, in Patos Lagoon, Brazil. Hydrobiologia 515: 3948.

Alvarenga, E. R., N. Bazzoli, G. B. Santos, and E. Rizzo, 2006. Reproductive biology and $\mathrm{f}$ eeding of Curimatella lepidura (Eigenmann \& Eigenmann) (Pisces, 
Curimatidae) in Juramento reservoir, Minas Gerais, Brazil. - Revista Brasileira de Zoologia 23: 314-322.

Avise J.C. end J.E. Mank 2009. Evolutionary perspectives on hermaph- roditism in fishes. Sex Dev 3:152_163.

Batlouni, S. R., E. Romagosa, and M. I. Borella, 2006. The reproduc- tive cycle of male catfish Pseudoplatystoma fasciatum (Teleostei, Pimelodidae) revealed by changes of the germinal epithelium. An approach addressed to aquaculture. Animal Reproduction Science 96: 116132.

Bromage, N., M. Porter, and C. Randall, 2001. The environmental regulation of maturation in farmed finfish with special references to the role of photoperiod and melatonin . - Aquaculture 197: 63-69.

Cinquetti, R. and L. Dramis, 2003. Histological, histochemical and enzyme histochemical and ultrastructural investigations of the testis of Padogobius martensi (Pisces,Gobidae) between breeding seasons. - Journal of Fish Biology 63: 1402.

Effendie M.I. 1979. Biologi Perikanan I. Yayasan Dewi Sri, Bogor. 122 hal.

Efizon D., O.S. Djunaedi, Y. Dhahiyat dan B. Koswara. 2012. Kelimpahan Populasi dan Tingkat Eksploitasi Ikan Terubuk (Tenualosa macrura) di Perairan Bangkalis, Riau. Berkala Perikanan Terubuk. 40(1): 52-65.

Fahy D.P., R.E. Spleler dan W.C. 2007. Hamlett. Preliminariy observation on the reproductive cycle and urine fecundity of the Yellow Stingray, Urobatisjamaicencis (Elasmobranchii: Myliobatiformes: Urolophidae in Southeast Florida, USA.Rafples Bulletin Zoology. 14: 131139.

Fiszbein, A., Ca nepa, M., Rey Va zquez, G., Maggese, C. and Pandolfi, M. 2010. Photoperiodic modulation of reproductive physiology and behaviour in the cichlidfish Cichlasoma dimerus. Physiology \& Behavior 99: 425-432.

Medeiros V.V., J. Anchieta, J.C.C. Nunes dan C. L. S. Sampaio 2009. A mutton hamlet Alphestes afer (Bloch, 1793) reproductive event in northeast Brazil. Pan-American
Journal of Aquatic Sciences, 4(2): 212215.

Sadovy de Mitcheson Y. and M. Liu. 2008. Functional hermaphroditism in teleosts. Fish Fisheries 9:1-43.

Singh, R., S. K. Chaturvedi, and Abhinav 2010. Effect of photoperiod and temperature on testicular regression in Channa punctatus. Journal Environmental Biology 31: 307310.

Sokołowska E. dan K. E. Skóra. 2002.

Reproductive cycle and the related spatial and temporal distribution of the ninespine stickleback (Pungitius pungitius L.) in Puck Bay. Oceanologia, 44 (4), 475-490. Wang H.Y., C.F. Weng, M.C. Tu dan S.C. Lee. 2001. Symchronization of plasma sexual steroid cocentration and gonadal cycles in the Sleeper, Eleotris acanthopoma. Zoological Studies 40(1): 14-20. 